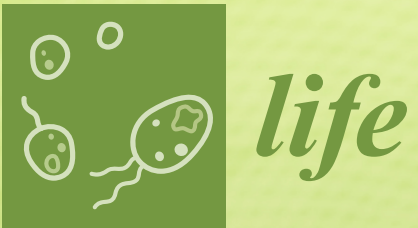

an Open Access Journal by MDPI

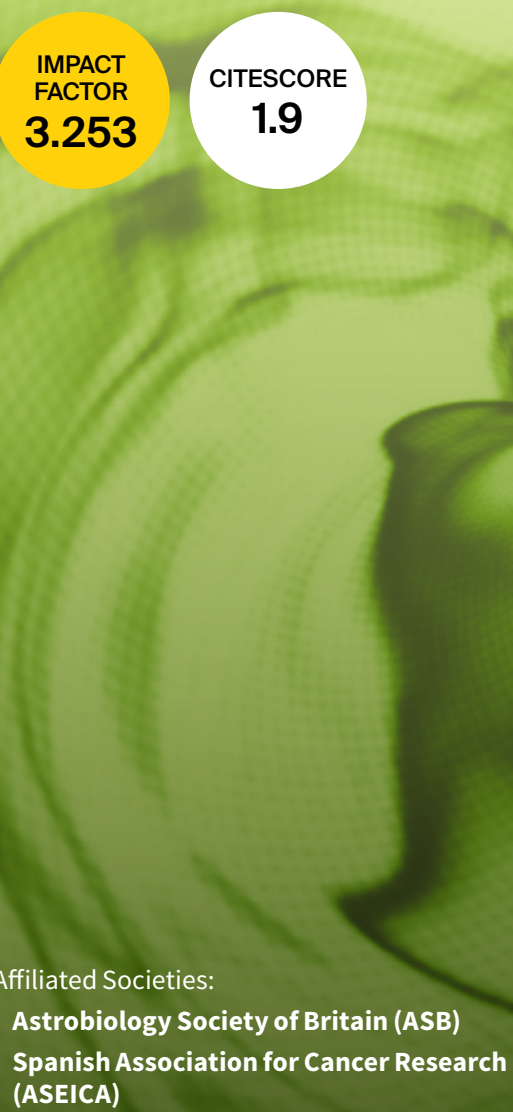

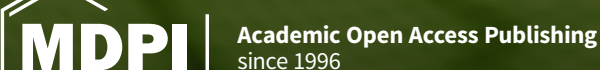




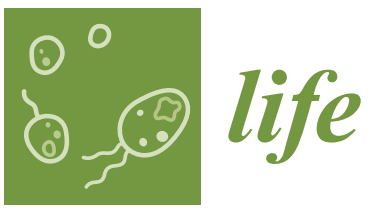

an Open Access Journal by MDPI

Section Editors-in-Chief

Dr. William Bains

Prof. Dr. Ramón Cacabelos

Prof. Dr. Ron Elber

Dr. Daniele Focosi

Prof. Dr. Stefano Gianni

Prof. Dr. Kousuke Hanada

Prof. Dr. Renate Kunert

Prof. Dr. Doron Lancet

Prof. Dr. Bruce Nicholson

Prof. Dr. Andrew Pohorille

Prof. Dr. Katalin Prokai-Tatrai

Prof. Dr. Pabulo H. Rampelotto

Prof. Dr. Lluís Ribas de Pouplana

Prof. Dr. Einar Ringø

Prof. Dr. Nicola Smania

Prof. Dr. Pasquale Stano

Prof. Dr. Koichiro Tamura

\section{Message from the Editors-in-Chief}

Life (ISSN 2075-1729) is an international, peer-reviewed open access journal that publishes scientific studies related to fundamental themes in life sciences. Some papers are published individually, while others are submitted for inclusion in special issues with guest editors. You are invited to contribute a research article, essay, or a review to be considered for publication.

\section{Author Benefits}

Open Access Unlimited and free access for readers

C No Copyright Constraints Retain copyright of your work and free use of your article

\section{\& Thorough Peer-Review}

IIF 2021 Impact Factor: 3.253 (Journal Citation Reports - Clarivate, 2022)

$\mathrm{D}$ Coverage by Leading Indexing Services Scopus, SCIE (Web of Science), PubMed, PMC, CAPlus / SciFinder, AGRIS, and other databases

I] No Space Constraints, No Extra Space or Color Charges No restriction on the length of the papers, number of figures or colors

Rapid Publication First decision provided to authors approximately 13.4 days after submission; acceptance to publication is undertaken in 2.8 days (median values for papers published in this journal in the second half of 2022) 


\section{More Information about This Journal}

This journal covers all aspects of life sciences. Research fields of interest include but are not limited to:
Abiogenesis
Artificial life
Astrobiology
Biochemistry
Biodiversity
Biomedicine

Biophysics

Cell biology

Ecology

Extremophiles

Evolutionary biology

Genetics

Genomics

Microbiology

Origins of life

Paleontology

Prebiotic chemistry

Systems biology

Synthetic biology

Editorial Office

Life Editorial Office life@mdpi.com MDPI, St. Alban-Anlage 66 4052 Basel, Switzerland Tel: +41616837734 www.mdpi.com mdpi.com/journal/life 


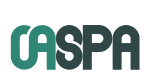

The Association of Learned \& Professional Society Publishers

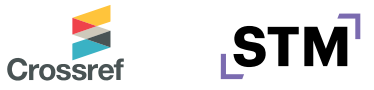

C $|\mathbf{O}| \mathbf{P} \mid \mathbf{E}$

SPARC*

Europe

\section{DOAJ}

\section{aseica}

\section{Follow}

f facebook.com/MDPIOpenAccessPublishing

3. twitter.com/MDPIOpenAccess

in linkedin.com/company/mdpi

(O) instagram.com/mdpiopenaccess

6) weibo.com/mdpicn

Wechat:MDPI-China

\section{Subscribe}

blog.mdpi.com

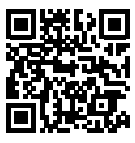

